\title{
Greek khrómis between sound and smell. Anthropozoology of a fish
}

Andrea GUASPARRI

Università degli Studi eCampus,

Via Isimbardi10, I-22060 Novedrate, Como (Italy)

andrea.guasparri@uniecampus.it

Published on 30 December 2016

Guasparri A. 2016. - Greek khrómis between sound and smell. Anthropozoology of a fish. Anthropozoologica 51 (2): 105-113. http://doi.org/10.5252/az2016n2a3

KEY WORDS

Sciaenidae,

Pomacentridae, ethnobiological names, Greek-Latin fish names, Ovid's Halieutica immunda chromis,

brown meagre, shi drum, damselfish.

MOTS CLÉS

Sciaenidae, Pomacentridae, noms ethnobiologiques, noms gréco-latins de

Halientic pons, immunda chromis, corb commun ombrine côtière, castagnole.

\section{ABSTRACT}

The Greek and Latin world viewed khrómis as essentially a vocal fish and a highly esteemed one, which does not match the identification, provided by Rondelet and ratified by Linnaeus, with the Mediterranean damselfish, Chromis chromis (Linnaeus, 1758) (also extended to the other pomacentrids of the genus Chromis). Trying to explain the reason behind Rondelet's misidentification deepens our understanding of the anthropozoology of the fish actually called khrómis by the ancients (in fact a sciaenid, most likely the shi drum, Umbrina cirrosa (Linnaeus, 1758)), while at the same time providing a possible interpretation to immunda chromis (lit. 'unclean chromis'), an obscure syntagm found in Ovid's (?) Halieutica.

\section{RÉSUMÉ}

Le grec khrómis entre son et odeur. Anthropozoologie d'un poisson

Le monde gréco-latin considérait khrómis essentiellement comme un poisson vocal et très apprécié, ce qui ne concorde pas avec l'identification, fournie par Rondelet et ratifiée par Linné, avec la castagnole méditerranéenne, Chromis chromis (Linnaeus, 1758) (étendu aussi aux autres pomacentridés du genre Chromis). Essayer d'expliquer les raisons de la mauvaise identification par Rondelet permet d'approfondir notre compréhension de l'anthropozoologie du poisson effectivement appelé khrómis par les anciens (en fait un sciaenidé, vraisemblablement l'ombrine côtière, Umbrina cirrosa (Linnaeus, 1758)), tout en fournissant en même temps une possible interprétation de immunda chromis (littéralement 'chromis impur'), une expression obscure qu'on trouve dans les Halieutiques, poème attribué à Ovide. 


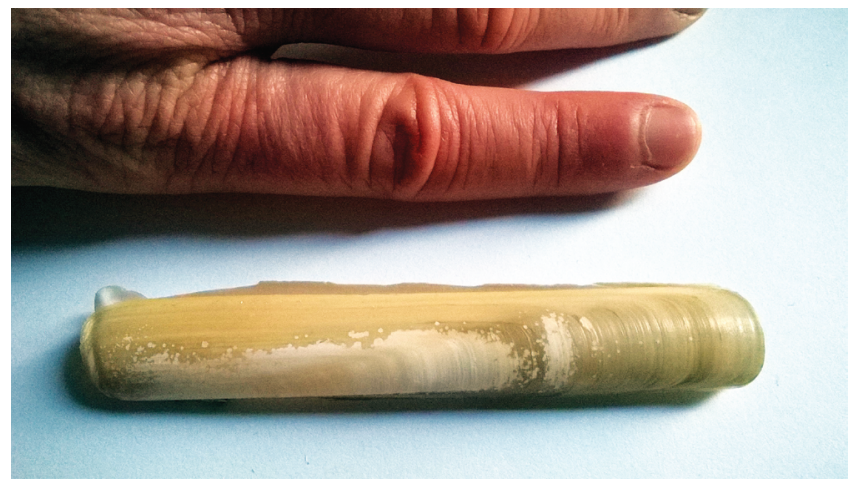

FIG. 1 - Definiens and definiendum: a human finger compared to Solen marginatus Pulteney, 1799, one among other mollusks called dáktulos (lit. 'finger'), or ónux (lit. 'nail') in Ancient Greek - e.g., Thompson 1947: 184 (Image by the author).

\section{INTRODUCTION}

The ancient Greek and Latin names of aquatic animals are mainly constructed as descriptive terms with metaphorical reference to a phenotypical, eco-ethological or generally cultural feature perceived as essential to the identity of the named organism (Bodson 2009, 2012, 2014; Guasparri 2010). This is not surprising, being one of the major naming patterns found in ethnobiological nomenclatures cross-culturally (Berlin 1992: 35). As to the nomenclatures in question, the use of descriptive ethnobiological names (hereafter ethnobionyms) is particularly high, which makes it especially engaging to investigate their linguistic morphology in search for the "referential constraint" linking the name to its biological counterpart (Guasparri 2007: 74; 2013: 350). Indeed, if names can generally tell us a great deal about how the members of a society relate to a given animal (e.g., Blanchard 2015), this is notably true for descriptive ethnobionyms, which can be explained on the basis of a similarity between a metaphorical subject (i.e. the organism that needs to be identified or definiendum) and a metaphorical predicate (i.e. the domain of experience that is familiar or definiens). Detecting this similarity and therefore both the definiens and the definiendum can be more or less tricky. Indeed, the more the metaphorical predicate is universal (for example when it coincides with the parts of the human body), the more the metaphor encoded in the name will be transparent or clear even for us - cf., for instance, a mollusk with an elongated shell called "finger" (Fig. 1); the reverse is true in the case of metaphorical implications related to more culture-dependent domains, such as ritual, magic, etc. - cf. a flat fish called by the name of a musical instrument (Fig. 2).

\section{UNEARTHING THE ANTHROPOZOOLOGY OF GR. KHRÓMIS}

It is particularly in these latter cases - the more culture-dependent ones - that the analysis of descriptive ethnobionyms may allow us to reconstruct how the members of any culture, even a dead one, perceived, and ultimately lived, their unique anthropozoological


FIG. 2. - A, Round-based zither (kithára). Detail from a red-figure vase painting, about 430 BCE - cf. Lexicon Iconographicum Mythologiae Classicae, Apollon 691a (Image by the author); B, Wide-eyed flounder, Bothus podas (Delaroche, 1809 ), a fish called kitharos by the ancient Greeks for its similarity to a roundbased kithára. Cf. Guasparri 2005: 216 (Image courtesy of Laguna Project).

reality (although only limited bits of it can be disclosed). And since in our case such a reality can be only reconstructed through written sources, our knowledge of how the ancients perceived an animal can be useful in fields as different as philology (i.e. the "correct" interpretation of the ancient texts) or scientific nomenclature (or at least its history). Gr. khrómis is a good case in point.

This is a descriptive ethnobionym whose definiendum is a fish described by Aristotle $(H A, 535 \mathrm{~b}, 17)$ as producing a sort of grunting noise (grulismós), as having the most sensitive hearing (Aristotle $H A, 534 \mathrm{a}, 9)$ and suffering in winter because of the stone in the head (Aristotle $H A, 601 \mathrm{~b}, 30$ ) - what biologists call otoliths. A praised fish according to Ananius (ap. Ath. 7, 282b), khromis is the best in spring. The animal is traditionally identified with a member of what biologists call Sciaenidae, a taxonomic family also known as "croakers" or "drums" because of the sound they produce (Ramcharitar et al. 2006). The members of this taxon, whose multi-branched swim bladder is used as a resonating chamber, are actually considered as "probably the most active sounds producers among fish" (Ramcharitar et al. 2006: 1426). Significantly enough, these fish have "exceptionally large 


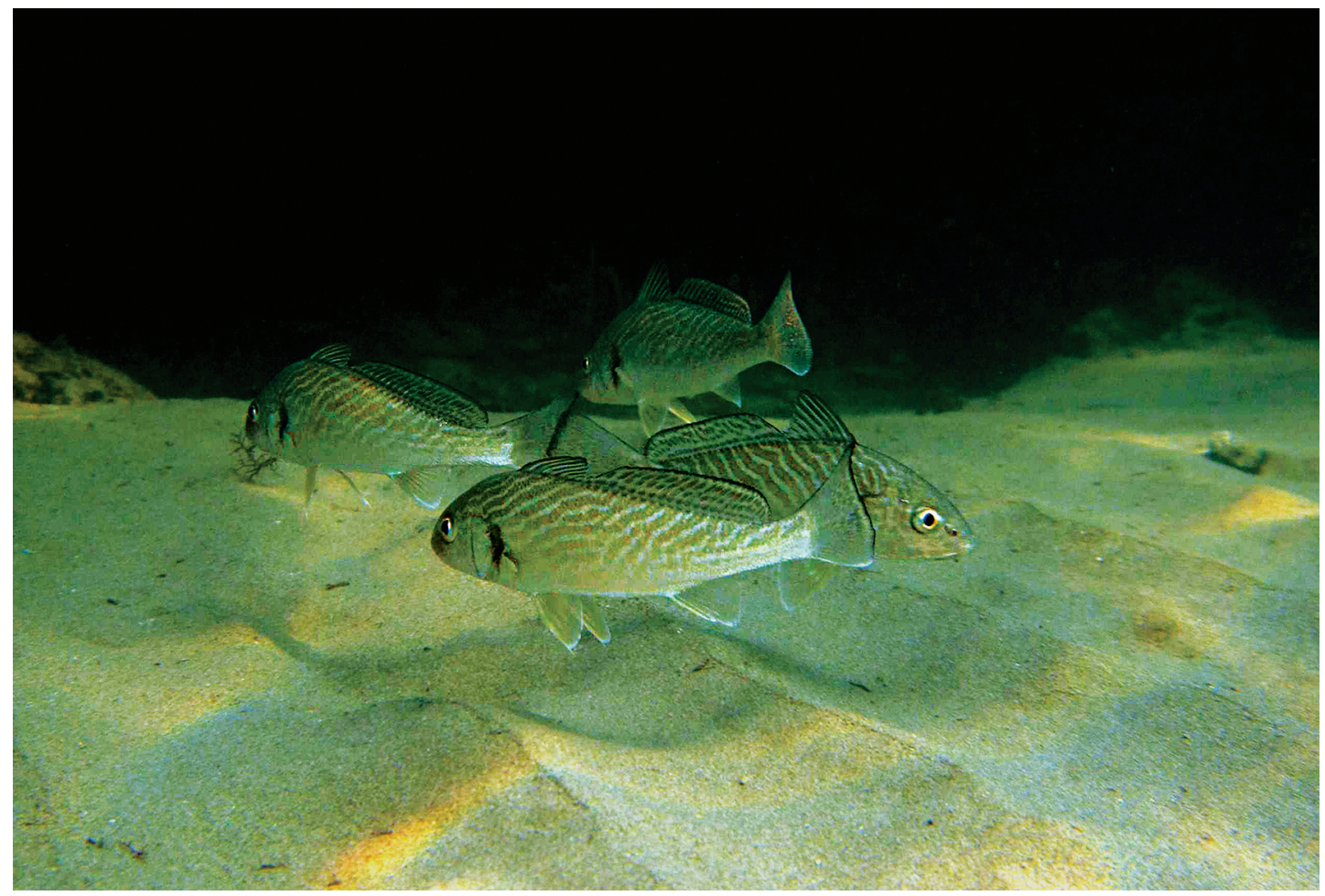

FIG. 3. - Shi drums (Umbrina cirrosa (Linnaeus, 1758)) in their natural environment (Image courtesy of Laguna Project).



FIG. 4. - Brown meagres (Sciaena umbra Linnaeus, 1758) in their natural environment (Image E. Sáez Goñalons \& V. Martínez Moll, wikimedia.org; CC BY 3.0). 



Fig. 5. - A, Chromis chromis (Linnaeus, 1758) and B, Umbrina cirrosa (Linnaeus, 1758) as reproduced in Aldrovandi (1613) after the original engravings in, respectively, Rondelet (1554) and Belon (1553). Notice the lack of proportion (common length for Chromis chromis is $13 \mathrm{~cm}$ vs $40 \mathrm{~cm}$ for Umbrina cirrosa; cf. Froese \& Pauly 2016). Image courtesy of Biblioteca Digitale Università di Bologna.

otoliths" (Bailly 2015a) that are reported to be still used in traditional medicine as a remedy for urinary tract infections (Bailly 2015b), which is exactly what Pliny says, although with regard to the otoliths of another species (Pliny Nat. 32, 102; cf. Duffin 2007: 80). As to their having a most sensitive hearing, this too has been confirmed by modern biologists (Wysocki et al. 2009: 2104) - although the question remains how Aristotle and/or his informers have correctly reached this conclusion: otoliths' size? Fishing experience? A detail provided by Aelian (the fish has a conspicuous chin barbel) ${ }^{1}$ may even lead to identify khrómis more precisely with members of the genus Umbrina Cuvier, 1816, such as the shi drum, Umbrina cirrosa (Linnaeus, 1758) (Fig. 3). In fact, given their similarity, it is very likely that also the brown meagre, Sciaena umbra Linnaeus, 1758 (Fig. 4), had been called khrómis by the ancients (cf. Thompson 1947: 291f) ${ }^{2}$. This is normal, since there is not - and there can never be - an exact correspondence between scientific classification and the biological taxonomies of local groups (the former as well is indeed a cultural construction; cf. Anderson 2011: 4).

\section{RONDELET VS BELON}

Anyway, the identification of khrómis with Umbrina cirrosa dates back at least to Pierre Belon (Belon 1553: 112ff), one of the "five great naturalists of the sixteenth century" (Gudger 1934).

1. Aelian $N A 15,11,27$. Aelian has the alternative form khrémēs, which is perfectly consistent with the etymology of khrómis (see etymology provided next). 2. This is the situation nowadays, as confirmed by the names these fish share in the Mediterranean area. See, e.g., the common names of shi drum and brown meagre in Froese \& Pauly 2016.
Guillaume Rondelet, however, the other major French ichthyologist of the Renaissance, reached a different conclusion from his contemporary and colleague by suggesting another species: the Mediterranean damselfish, Chromis chromis (Linnaeus, 1758) (Rondelet 1554: 152f). The divergence between the two naturalists is meaningfully represented in iconographical terms by Ulisse Aldrovandi, as the original captions to the engravings in his De piscibus (Aldrovandi 1613: 168) explicitly show (Fig. 5):

Clearly these are two very different fish. The Mediterranean damselfish (Fig. 6) is indeed assigned by biologists to the taxonomic family Pomacentridae, which mostly comprises coral reef fish (Allen 1991). Apart from other major morphological differences, the Mediterranean damselfish does not have particularly conspicuous otoliths, is considerably smaller than the shi drum and, contrary to the sciaenids, not particularly esteemed (Ramcharitar et al. 2006: 1426).

However, when it comes to sound emitting abilities, the pomacentrids as well are considered by biologists as typical "vocal" fish, i.e. fish that expressly produce sounds for communication purposes (Amorim et al. 2015: 3ff; Ladich 2015). Sounds are characteristically produced by males mostly to attract females during courtship (Picciulin et al. 2010: 126; Amorim et al. 2015) or during agonistic interactions with other males (Amorim 1996: 266; Picciulin et al. 2002: 237). Since tropical damselfish are quite popular aquarium fish, the detection of their vocal products is frequently reported by fish-keepers (and sometimes also by divers) ${ }^{3}$. But these reports do not involve Chromis chromis, the only damselfish living in the Mediterranean Sea. The same seemingly goes for the ancients: although, as a common fish forming shoals near rocky reefs, it is not to be excluded that the ancients had been aware of its vocal abilities, no ancient text reports anything of the sort for korakinos - the Greek name for Chromis chromis (Saint-Denis 1947: 27f; Thompson 1947: 122f; Guasparri 2005: 148). The name is derived from kórax 'crow', seemingly in reference to the dark colour of the fish (e.g., Aristophanes ap. Ath. 7, 308f; Oppian Hal. 1, 133). Its taste, as expected, is deplored by the ancients (eg., Archestratus ap. Ath. 7, 294a; Amphis ap. Ath. 7, 309d). Currently only biologists seem familiar with its sounds, described as "pops" consisting of single pulses peaking at about $400 \mathrm{~Hz}$ and recorded both at sea or in tanks during aggressive and courtship behaviours (Picciulin et al. 2002: 272; 2010: 126).

On the contrary, the sciaenids are well known as vocal fish also beyond the biological field, as their common English names clearly attest (see above) - e.g., brown meagres are easily detected (unfortunately for them) by spear fishermen, who can tell not only where but also how big they are by the type of "frogs' croaking sounds" they emit (Volpe 2004). "These sounds are fairly audible even from out of the water when there are several animals involved (chorus) and therefore are easier to learn" (Picciulin pers. comm.).

3. The internet has many videos documenting this e.g., (as of January 2016), https://www.youtube.com/watch?v=hH8pUZyFmxk 


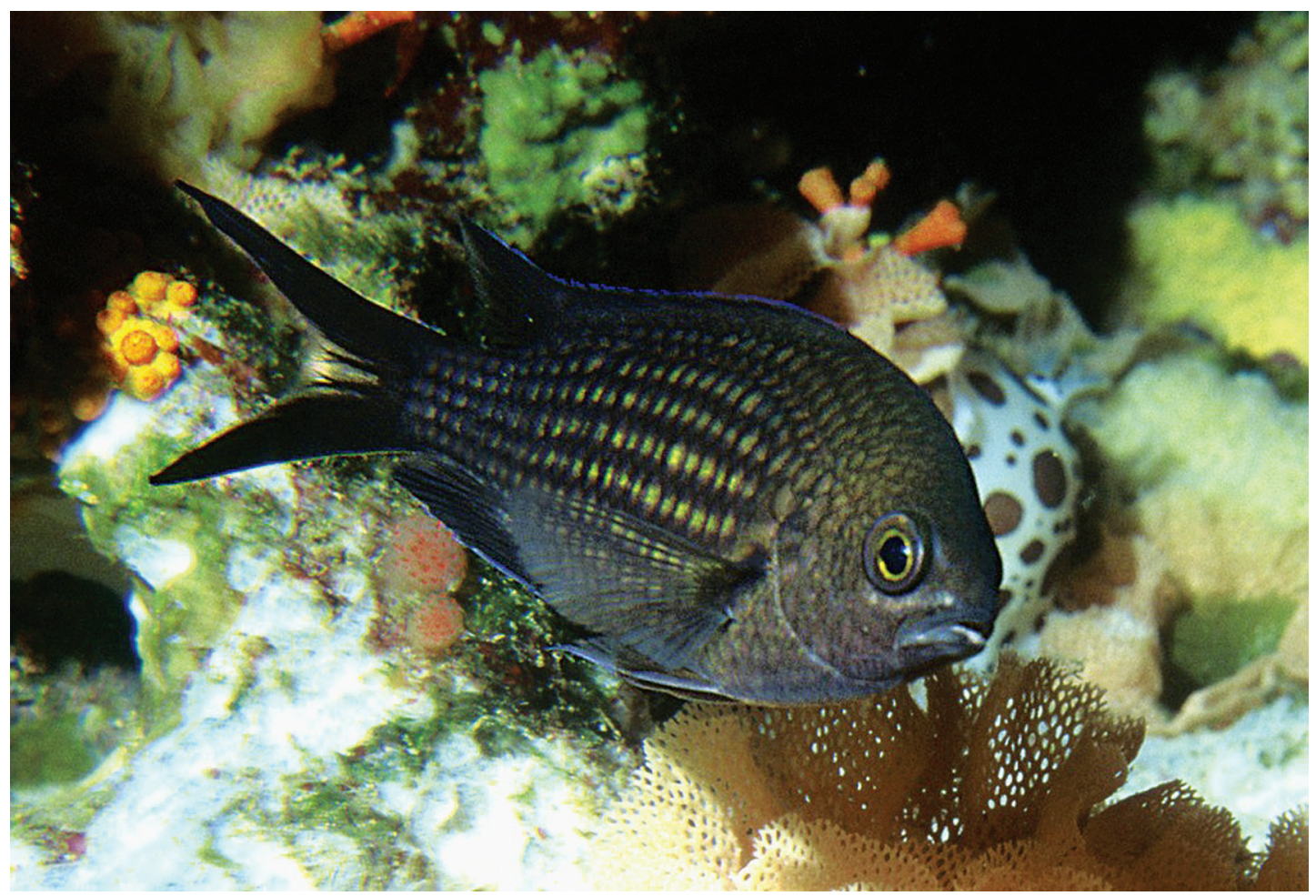

FIG. 6. - A Mediterranean damselfish (Chromis chromis (Linnaeus, 1758)) in its natural environment (Image A. Kok, wikimedia.org; public domain).

Picciulin also confirms that the sounds emitted by Sciaena umbra and Umbrina cirrosa are similar (cf. also Picciulin et al. 2013: 77).

\section{"NEIGHING” FISH OR “GRUNTING” ONES?}

As a consequence, sound emitting can definitely make a salient trait in the cultural construction of the sciaenids' identity. This does not only go for contemporary cultures ${ }^{4}$, but appears to be also true for the members of the cultures in question. Indeed, it is precisely such referential constraint that appears encoded in the morphology of the Greek descriptive ethnobionym.

Linguistically, khrómis, like many other nouns in $-i-$, is derived from a nominal base which is in turn derived from a verb, although with an $o$-grade, instead of an $e$-grade, in the root syllable (Buck \& Petersen 1945: 14f; Chantraine 1933: 112). In particular, the ethnobionym appears to be formed as $\left[[k b r o m o / e \bar{e}]_{\mathrm{N}}+i\right]_{\mathrm{N}}+s$, i.e. from such nouns as khrómos or khrómè 'the neighing of horses' (Liddell et al. 1940: 2008), both connected to the verb *khrémō, analogically reconstructed from such attested forms as khremetizo, khremizo "neigh". By analogy with the other morpho-

4. In addition to the names given above cf. the "crow-related" ones spread in the Mediterranean area for the shi drum and the brown meagre (e.g., It. corvo, Ar. g'rab, Alb. korb, etc.). See the common names of both in Froese \& Pauly 2016.

5. Cf. also khrémès (gen. -tos), a variant of khrómis found in Oppian (Hal. 1, logically parallel forms, the semantics of the suffix can be generally expressed as 'someone or something provided with $\mathrm{x}$ ' (where $\mathrm{x}$ is represented by a trait hyponymically related to the semantics of the derivational base $-\mathrm{cf}$. the examples in Buck \& Petersen 1945: 14; see also Guasparri 2005: 115). Thus khrómis will be a fish 'provided with a neigh' (cf. Strömberg 1943: 67; Chantraine et al. 1968-80: 1272). However, a neigh is very different from a croaking sound, a drum-like sound or, at any rate, a sound like the ones actually produced by the Mediterranean sciaenids.

In fact, although the nouns khrómos or khrómé and the related verbs khremizö/khremetizo are glossed in the dictionaries as 'neigh, whinny' (cf. Liddell et al. 1940: 2003), such definitions appear incorrect if we think only in terms of the high-pitched prolonged sound we consider typical of a horse; horses also typically emit a grunting noise, and, by comparing the semantics of other forms connected with the verb khremizo or khremetizō, it appears that it is to the latter sound that the Greek name may refer to. The term $k h r o ́ m e \bar{e}$, for instance, is only found in Hesychius ( $\varphi$ 753) with the gloss phruagmós, a parallel form to phruagma 'violent snorting' (Liddell et al. 1940: 1958), also said of the sound produced by a boar in Oppian (Cyn. 2, 457). Moreover, such related forms as Khremétès, a river name (lit. 'croaker'?), khrómados, used in the Iliad $(23,688)$ for the creaking sound of the boxers' jaws being hit with a

$112)$ and Aelian $(N A 15,11)$ - see note 1 above. For the sake of completeness cf. also the fish name khrémus in Hesychius ( $\chi 696$ ), whose gloss, however, refers to oniskos, the European hake, Merluccius merluccius (Linnaeus, 1758). 
blow, and, most significantly, khrémps (cf. khrémptomai 'clear one's throat' - see Strömberg 1943: 67; Chantraine et al. 1968-80: 1272), a variant form of khrómis found in Aristotle (HA 534a8), confirm that the sounds emitted by this fish resemble the croaking sounds produced by Umbrina sp. (or Sciaena umbra) rather than the "pops" produced by the Mediterranean damselfish.

\section{AN UNDERSTANDABLE (MIS)IDENTIFICATION}

The identification of Greek khrómis seems, therefore, exclusively limited to fish of the Sciaenidae family such as the shi drum and the brown meagre.

How to explain, then, the identification with the damselfish provided by Rondelet and accepted as such by most ichthyologists after him? Answering this question will lead us to both clarifying the interpretation of a passage from the Halieutica (a poem traditionally ascribed to Ovid) and, incidentally, putting in doubt - but only from a historical point of view - the scientific taxonym biologists use for referring to the genus Chromis, a fairly numerous taxon comprising fish of the Pomacentridae (not the Sciaenidae) family - notably, the name has been assigned by Linnaeus himself based on Artedi's authority, the latter based in turn on Rondelet's identification of Gr. khrómis with the Mediterranean damselfish (Artedi 1738; Linnaeus 1758: 280).

Rondelet's succinct paragraph about khrómis ends with the quotation of Ovid's remark immunda chromis (Ov. Hal. 121), lit. 'unclean chromis', the only negative statement about the fish in the ancient sources and, therefore, easier to pinpoint.

Rondelet, much like many other scholars after him (e.g., Aldrovandi 1613: 168; Saint-Denis 1947: 23; Capponi 1972: 529), has taken the adjective as referring to the qualities of the fish as food, which cannot match with the tremendous reputation of the sciaenids. The bad reputation of the Mediterranean damselfish, maybe only second to that of the saupe (Sarpa salpa (Linnaeus, 1758)), whose discredit goes for the ancients as well (e.g., Epicharmus ap. Ath. 7, 321d; Pliny Nat. 9, 68), will have played a primary role - what is more, when it comes to fish that thrive in grassy sand, Ovid's verse mentions just the saupe as merito vilissima ('rightly most worthless') immediately after immunda chromis, a pairing which might have been difficult to resist for Rondelet and his followers, although the fish lists in the poem do not follow the criterion of phenotypical similarity. Moreover, Pliny (Nat. 32, 153) quotes chromis among the fish quoted in turn by Ovid, saying that it builds a nest underwater. This might be the only actual reference to the Mediterranean damselfish in the ancient texts, since these fish are "nesters" (Quignard \& Pras 1986), unlike the Sciaenidae - Thompson (1947: 292), for instance, relies both on this fact and on Ovid's immunda remark for additionally identifying khromis with the Mediterranean damselfish. In fact, Ovid's passage assigns this reproductive habit not to chromis but to phycis (= the wrasse Symphodus sp., another "nester" fish; see Guasparri 2005: 368); the fact that phycis is mentioned in the verse immediately fol- lowing the one where chromis appears (Hal. 122) may explain Pliny's (or maybe the copyist's) misreading (cf. Aldrovandi 1613: 168; Saint Denis 1947: 23).

\section{LAT. IMMUNDUS}

As to the adjective immundus, this is never used in the Latin sources in reference to (bad) gastronomic qualities. The word occurs from Plautus onwards mostly in its denotative meaning, i.e. for describing something "unclean or untidy in appearance" (Glare 1968: 838), which seems rather odd for a fish.

Thus, all possible explanations of the syntagm immunda chromis rest on the connotative uses of immundus. However rare in the ancient texts, such occurrences are well worth considering in detail. By reviewing all the occurrences found in the Latin sources, two seem the semantic spheres targeted through the metaphorical use of immundus ${ }^{6}$. The first is connected with smell. Virgil $(G .3,564)$ says immundus of the sweat secreted by the smelling limbs of someone wearing clothes made out of the wool of plague-affected sheep ${ }^{7}$. The other smell-related passage is particularly significant because it is not only found in Ovid himself but it also involves an animal (although not a fish). Drawing an analogy between human and non-human sexual behaviours, Ovid (Ars 2, 486) says that a she-goat "bears her immundus male". Even though the reference to smell might not appear explicit to us city-dwellers, he-goats are mostly quoted throughout Latin literature as the standard example of a stinking animal (cf. e.g., MacCary \& Willcock 1976: 210) - Pliny, for instance, labels the he-goat as foedissimum animalium, lit. 'the foulest of animals' (Pliny Nat. 37, 60).

The second connotational field attested for immundus in the Latin texts is taboo-related. Horace uses the adjective for describing the erotic dream (immundum visum) which leads him to stain his nightshirt ${ }^{8}$. The same author labels the language of the Satyrs in satyric dramas as filled with immunda dicta, i.e. "obscene" or "bawdy words" (Horace Ars 247; cf. e.g., Fairclough 1942: 471).

\section{KHRÓMIS, SAPÉRDËS AND KORAKĨNOS: A "PONTIC" SYNONYMY}

In view of the above connotative uses, let us try and explain why Ovid has called this sciaenid fish immundus. Everything relies on two additional Greek fish names: sapérdès and, again, korakinos.

Sapérdès labels both a food item consisting of salted fish (tárikhos) typically prepared in the Black Sea region (Pontus; cf. Varro Men. 312; Persius 5, 133; Archestratus ap. Ath. 3, 117a) and the fish called by the same name - a pairing food/fish which

6. In particular, out of a total of 29 occurrences, two are taboo-related (Horace S. 1, 5, 84; Ars 247) and two smell-related (Ovid Ars am. 2, 486; Virgil G. 3, 564). All the rest consists of denotative uses (i.e. immundus as 'unclean').

7. "Foul sweat" as the English translation for immundus sudor is well established among Virgil scholars. E.g., Fairclough 1934: 195; Thomas 2008: 64.

8. Cf. e.g., translations such as "salacious" (Schlegel 2005: 65) and "obscene" (Brown 1993: 59). 
is not uncommon in both the ancient Greek and the Latin world, which typically viewed the sea as an inexhaustible larder (Guasparri 2005). In the same Pontic area this fish is also called korakinos (cf. Hesychius, $\sigma$ 184), the most esteemed of which is found in the Palus Maeotis (Sea of Azov) (cf. Dorius ap. Ath. $3,118 \mathrm{~b}$ ). But what species is it? Korakinos (see etymology given earlier) has a threefold identification, one of which involves just the two sciaenids we have considered so far to be the referents of khrómis (cf. Thompson 1947: 122f). This identification is not only supported by the similarity between the ancient and the modern names of the two fish involved (all "crow-related") ", but, above all, by sapérdès being described as a "big" fish (Diphilus ap. Ath. 4, 157a) and a "broad-snouted" one (Timocles ap. Ath. 7, 339e), which definitely excludes both the other referents denoted by korakinos (the damselfish and - for different but obvious reasons - the Nile tilapia, Oreochromis niloticus (Linnaeus, 1758)), all to the advantage of the two sciaenids - and of the shi drum in particular, given its "massive head" (Costa 1991: 188).

We can therefore conclude that all three ethnobionyms, khrómis, sapérdès and korakinos, denote the shi drum (or the brown meagre), although, as to korakinos, this reference is seemingly only found in the Black Sea region. This, however, is hardly a problem, since, according to Pliny (Nat. 32, 152), Ovid has begun his book when in exile on the Black Sea at the end of his life and, therefore, he has included fish typically found there.

As a result, although referring to sapérdès, Ovid might have used khrómis hinting at its "Pontic" synonymy with both korakinos and sapérdès. This hypothesis, i.e. Ovid's allusion to the scienids in question through the adjective immunda, can actually be strongly supported in terms of both the connotative uses of immundus seen earlier. A first case in point is provided by Athenaeus: Parmeniscus, one of "the learned banqueters" portrayed in the Deipnosophists, quotes a verse by the comic poet Diphilus in which a "big" and "somewhat smelly" ( hupodusódès) sapérdès makes its entrée at a "flowery" dinner table, which is possibly (the text is partially corrupt) what brings a burst of laughter from the other banqueters.

The second case in point is provided by Strabo (geogr. 13, 2, 6), who quotes sapérdès among several other "indecent" words writers avoid because of the phonetic connection to such taboo-terms as pordé 'flatulence' and pérdomai 'break wind': "Some writers, to avoid the indecency of the names, say that in this place we should read "Poroselene", and that we should call Aspordenum, the rocky and barren mountain round Pergamum, "Asporenum," and the temple of the Mother of the Gods there the temple of the "Asporene" mother. What, then, shall we say of Pordalis and Saperdes (Sapérdēs) and Perdiccas, and of the phrase of Simonides, "banished, 'pordacian' clothes and all", instead of "wet" clothes, and, somewhere in the early comedy, "the place is 'pordacian'," that is, the place that is marshy"? (Jones 1929: 147).

This might not only explain Ovid's text both in terms of the smell and the taboo-related connotations of immundus (the fish would be "unclean" for both its smell as a tárikhos and its flatulence-like sound, hence the pun), but also account for Ovid's avoidance of sapérdès in his poem.

9. See e.g., Thompson 1947: 122; Froese \& Pauly 2016.
But what about korakinos, the synonym which both fish names share? Why not use it?

Korakinos is commonly the damselfish for both Greek and Latin speakers, but, as just seen, not in Pontus, where it labels the sapérdès, or rather what is commonly also called khrómis. Thus the latter seems the only ethnobionym available to Ovid, and not only because it unequivocally denotes the same fish as sapérdès, but also because of its anthropozoological identity: indeed its morphology bears a semantic/onomatopoeic relation to the "croaking" sound produced by the fish, which is key for letting the reader grasp the underlying smell/sound associations and therefore the pun resulting from the ethnobiological pairing with sapérdès, a fish sauce well known in Rome and, perhaps not incidentally, only found in the works of satiric poets such as Lucilius (1, 54 Marx), Varro (Men. 312) and Persius $(5,134)-$ it is not to be excluded that also Diphilus, a comic poet, may hint at not just the pungent smell of the rotting sauce but also at the flatulence-related sound when labelling the fish as "somewhat smelly" (see above).

Such a verbal play seems to perfectly match the only apparently frivolous parody of didactic poetry which is embodied in the Halieutica (Toohey 2004: 237) - be it the work of Ovid or of one of his many (gifted) imitators. Indeed, if there is a Latin poet that can be considered the master of word-play, constantly challenging his readers on the multivalence of his verses, it is Ovid (e.g., Ahl 1985; Papaioannou 2005). Even in his exilic works he simply cannot resist multi-layered verbal ambiguities, be they double entendres, puns, riddles, etymological plays etc. (e.g., Claassen 2008: 134).

\section{CONCLUSION}

To sum up and return to the main goal of this article, the above is yet another example of why the traditional identification of Gr. khrómis with the Mediterranean damselfish should be rejected, all to the advantage of the two scienids considered so far, and of the shi drum in particular. First of all, this identification makes it possible to deepen our understanding of the anthropozoological identity of the fish in question as it emerges from both the (sound-related) etymology of its descriptive ethnobionym and the otherwise inconsistent testimonies found in ancient authors. Secondly, it questions the current scientific name of both the Mediterranean damselfish, i.e. Chromis chromis (Linnaeus, 1758), and the superordinate taxon, i.e. genus Chromis - Chromis chromis being the type species. However, inasmuch as Linnaeus's authority is involved, this can only be a matter of historical interest.

\section{Acknowledgements}

I am deeply indebted to Angela Giardino, for the French translation of abstract/keywords and for reading and commenting with the usual accuracy and patience; to Marta Picciulin, for providing me with precious information and data about the sound production of Chromis chromis, Sciaena umbra and Umbrina cirrosa. I am also especially grateful to Giuseppe 
Manganelli for his help and insightful advice on the taxonomy of Chromis chromis and to Laguna Project (http://www.lagunaproject.it) for providing me with pictures of Bothus podas and Umbrina cirrosa in their natural environment. Last but not least, I express my extreme gratitude to two anonymous reviewers whose insightful comments and suggestions have significantly helped me to improve this article.

\section{REFERENCES}

AELIAN: see SCHOLFIELD 2014

AHL F. 1985. - Metaformations: Soundplay and Wordplay in Ovid and Other Classical Poets. Cornell University Press, Ithaca, 352 p.

Aldrovandi U. 1613. - De piscibus libri 5 et De cetis lib. unus. apud Bellagambam, Bononiae.

Allen G. R. 1991. - Damselfishes of the World. Mergus, Melle, 271 p.

AMPHIS AP. ATH.: see OlsON 2008.

Amorim M. C. P. 1996. - Sound production in the blue-green damselfish, Chromis viridis (Cuvier, 1830) (Pomacentridae). Bioacoustics 6 (4): 265-272.

AMORIM M. C. P., VAsConcelos R. O. \& FonseCA P. J. 2015. Fish sounds and mate choice, in LADICH F. (ed.), Sound Communication in Fishes. Springer, Wien: 1-33.

ANANIUS AP. ATH.: see OLSON 2008.

ANDERSON E. N. 2011. - Ethnobiology: overview of a growing field, in Anderson E. N., Pearsall D. M., Hunn E. S. \& Turner N. J. (eds), Ethnobiology. John Wiley \& Sons, Hoboken NJ: 1-14.

ArChestratus AP. ATH.: see Olson 2008.

Aristophanes AP. ATH.: see OlsON 2008.

ARISTOTLE: see PECK 1970.

ARTEDI P. 1738. - Ichthyologia sive opera omnia de piscibus. apud Conradum Wishoff, Lugduni Batavorum.

Astbury R. (ed.) 2002. - M. Terentius Varro. Saturarum Menippearum fragmenta, Revised Edition. K.G. Saur, Muenchen, 155 p.

Athenaeus: see Olson 2008.

Bailly N. 2015a. - Sciaenidae Cuvier, 1829, in Froese R. \& Pauly D. (eds), Fishbase. http://www.marinespecies.org/aphia. php? $\mathrm{p}=$ taxdetails\&id $=125558$ last consultation: $28 / 09 / 2016$.

BaILlY N. 2015b. - Sciaena umbra Linnaeus, 1758, in Froese R. \& PAuly D. (eds), Fishbase. http://www.marinespecies.org/aphia. php?p=taxdetails\&id=127010 last consultation: 28/09/2016.

BELON P. 1553. - De aquatilibus, libri duo: cum eiconibus ad vivam ipsorum effigiem, quoad ejus potuit, expressis. apud Carolum Stephanum, Parisiis.

BerLIN B. 1992. - Ethnobiological Classification: Principles of Categorization of Plants and Animals in Traditional Societies. Princeton University Press, Princeton NJ, 335 p.

BLANCHARD C. 2015. - Ce que les noms des chiens des sans-abris révèlent de leurs maitres. Anthropozoologica 50 (2): 99-107. http:// doi.org/10.5252/az2015n2a3

BODSON L. 2009. — L'interprétation des noms grecs et latins d'animaux illustrée par le cas du zoonyme seps-sēps. Académie Royale de Belgique, Bruxelles, $368 \mathrm{p}$.

BODSON L. 2012. - Introduction au système de nomination des serpents en grec ancien: l'ophionyme dipsas et ses synonymes. Anthropozoologica 47 (1): 73-155.

BODSON L. 2014. - Zoological knowledge in ancient Greece and Rome, in CAmpBell G. L. (ed.), The Oxford Handbook of Animals in Classical Thought and Life. Oxford University Press, Oxford: 556-578. http://promethee.philo.ulg.ac.be/Zoologica/ lbodson/bibl/BODSON_Zool_Kn_2014.pdf last consultation: 28/09/2016.

Braund S. (ed., trans.) 2004. - Juvenal and Persius. Harvard University Press, Cambridge MA, 536 p. (Coll. Loeb Classical Library; 91).
Brown P. M. (trans.)1993. - Horace. Satires I. Aris \& Phillips, Warminster, $194 \mathrm{p}$.

Buck C. D. \& Petersen W. 1945. - A Reverse Index of Greek Nouns and Adjectives, Arranged by Terminations with Brief Historical Introductions. University of Chicago Press, Chicago, 765 p.

Capponi F. (ed.) 1972. - P. Ovidii Nasonis Halieuticon. Brill, Leiden, $615 \mathrm{p}$.

Chantraine P. 1933. - La formation des noms en grec ancien. Champion, Paris, 473 p.

Chantraine P., Blanc A., Lamberterie de C. \& Perpillou J.-L. 1968-1980. - Dictionnaire étymologique de la langue grecque: histoire des mots. Klincksieck, Paris, 4 volumes, $1368 \mathrm{p}$

ClaAssen J.-M. 2008. — Ovid Revisited: the Poet in Exile. Duckworth, London, $292 \mathrm{p}$.

Costa F. 1991. - Atlante dei pesci dei mari italiani. Mursia, Milano, $475 \mathrm{p}$.

DiphILUS AP. ATH.: see OLSON 2008.

DuFfin C. J. 2007. — Fish otoliths and folklore: a survey. Folklore 118 (1): 78-90.

EichHolz D. E. (trans.) 1962. — Pliny. Natural History, Volume X: Books 36-37. W. Heinemann, London; Harvard University Press, Cambridge MA, 343 p. (Coll. Loeb Classical Library; 419).

EPICHARMUS AP. ATH.: see OlSON 2008.

FairClOUGH H. R. (trans.) \& GoOld G. P. (ed.) 1934. - Virgil. Eclogues. Georgics. Aeneid: Books I-VI. W. Heinemann, London; Harvard University Press, Cambridge MA, 571 p. (Coll. Loeb Classical Library; 63).

Fairclough H. R. (trans.) 1942. - Horace. Satires, Epistles and Ars Poetica. W. Heinemann, London; Harvard University Press, Cambridge MA, 508 p. (Coll. Loeb Classical Library; 194).

Froese R. \& PAUly D. 2016. - Fishbase. http://www.fishbase.org last consultation: 28/09/2016.

Glare P. G. W. (ed.) 1968. — Oxford Latin Dictionary. Clarendon Press; Oxford University Press, Oxford, 2126 p.

GUASPARRI A. 2005. - Aquatilium vocabula ad similitudinem. Lessico antropo-linguistico degli animali acquatici nel mondo latino. Ph.D. Dissertation, Università degli Studi di Siena, 548 p.

GUASPARRI A. 2007. - Etnobiologia e mondo antico: una prospettiva di ricerca. Annali Online di Lettere Ferrara. Volume Speciale: Animali, animali fantastici, ibridi, mostri Supp. II (2): 69-90. http://doi.org/10.15160/1826-803X/271

GUASPARRI A. 2010. — La percezione è culturale? Studiare i nomi degli animali nel mondo antico in una prospettiva cognitivista, in BETA S. \& MARZARI F. (eds), Animali, ibridi, mostri nella cultura antica. Cadmo, Firenze: 157-166.

GUASPARRI A. 2013. - Explicit nomenclature and classification in Pliny's Natural History XXXII. Studies In History and Philosophy of Science Part A 44: 347-353. http://doi.org/10.1016/j.shpsa.2013.04.006

GUDGER E. W. 1934. — The five great naturalists of the sixteenth century: Belon, Rondelet, Salviani, Gesner and Aldrovandi: a chapter in the history of ichthyology. Isis 22 (1): 21-40.

HANSEN P. A. (ed.) 2005. - Hesychii Alexandrini Lexicon, Vol. 3: [Pi-Sigma]. De Gruyter, Berlin, New York, 404 p.

Hansen P. A. \& Cunningham I. C. (eds) 2009. - Hesychii Alexandrini Lexicon, Vol. 4: [Tau-Omega]. De Gruyter, Berlin, New York, $281 \mathrm{p}$.

Hesychius: see Hansen $2005(\Sigma)$, Hansen \& Cunningham 2009 ( $\Phi, \mathrm{X})$.

HORACE: See FAIRCLOUGH 1942.

ILIAD: see KIRK \& RICHARDSON 1993.

JONES H. L. (trans.) 1929. - Strabo. Geography, Volume VI: Books 13-14. W. Heinemann, London; Harvard University Press, Cambridge MA, 400 p. (Coll. Loeb Classical Library; 223).

Jones W. H. S. (trans.) 1963. - Pliny. Natural History, Volume VIII: Books 28-32. W. Heinemann, London; Harvard University Press, Cambridge MA, 593 p. (Coll. Loeb Classical Library; 418). LADICH F. (ed.) 2015. - Sound Communication in Fishes. Springer, Wien, $244 \mathrm{p}$. 
LeXicon ICONOGRAPHicum Mythologiae Classicae (LiMC). 1981-1999. Artemis, Zürich.

Liddell H. G., SCOTT R. \& Jones H. S. 1940. — A Greek-English Lexicon. Clarendon Press, Oxford, 2448 p.

LINNAEUS C. 1758. - Systema naturae per regna tria naturae: secundum classes, ordines, genera, species, cum characteribus, differentiis, synonymis, locis. Impensis Direct. Laurentii Salvii, Holmiae.

LUCILIUS: see WARMINGTON 1938.

MacCary T. \& Willcock M. M. (eds) 1976. - Plautus. Casina. Cambridge University Press, Cambridge, $243 \mathrm{p}$.

MaIr A. W. (trans.) 1987. — Oppian, Colluthus, Tryphiodorus. W. Heinemann, London; Harvard University Press, Cambridge MA, 633 p. (Coll. Loeb Classical Library; 219).

Mozley J. H. (trans.) \& Goold G. P. (ed.) 1979. - Ovid. The Art of love, and Other Poems. W. Heinemann, London; Harvard University Press, Cambridge MA, 381 p. (Coll. Loeb Classical Library; 232).

Olson S. D. (ed., trans.) 2008. - Athenaeus. The Learned Banqueters, Volume III, Books 6-7. W. Heinemann, London; Harvard University Press, Cambridge MA, 566 p. (Coll. Loeb Classical Library; 224).

OPPIAN: see MAIR 1987

OVID: see MOZLEY \& GOOLD 1979.

Papaionnnou S. 2005. - Epic Succession and Dissension: Ovid, Metamorphoses 13.623-14.582, and the Reinvention of the Aeneid. De Gruyter, Berlin, New York, 218 p.

PECK A. L. (trans.) 1970. - Aristotle. Historia Animalium, Volume II, Books IV-VI. W. Heinemann, London; Harvard University Press, Cambridge MA, 409 p. (Coll. Loeb Classical Library; 438).

PERSIUS: see BRAUND 2004.

Picciulin M., Costantini M., Hawkins A. D. \& Ferrero E. A. 2002. - Sound emissions of the Mediterranean damselfish Chromis chromis (Pomacentridae). Bioacoustics 12 (2-3): 236-238. http://doi.org/10.1080/09524622.2002.9753707

Picciulin M., Sebastianutto L., Codarin A., Farina A. \& FerRERO E. A. 2010. - In situ behavioural responses to boat noise exposure of Gobius cruentatus (Gmelin, 1789; fam. Gobiidae) and Chromis chromis (Linnaeus, 1758; fam. Pomacentridae) living in a Marine Protected Area. Journal of Experimental Marine Biology and Ecology 386 (1): 125-132. http://doi.org/10.1016/j. jembe.2010.02.012

Picciulin M., Bolgan M., Codarin A., Fiorin R., Zucchetta M. \& MALAVASI S. 2013. - Passive acoustic monitoring of Sciaena umbra on rocky habitats in the Venetian littoral zone. Fisheries Research 145: 76-81. http://doi.org/10.1016/j.fishres.2013.02.008 PLINY: see RACKHAM 1940 (9), JONES 1963 (32), EICHHOLZ 1962 (37).
Quignard J. P. \& Pras A. 1986. — Pomacentridae, in Whitehead P. J. P., Bauchot M.-L., Hureau J.-C., Nielsen J. \& TORTONESE E. (eds), Fishes of the North-eastern Atlantic and the Mediterranean. UNESCO, Paris: 916-918.

RackHAm H. (trans.) 1940. - Pliny. Natural History, Volume III: Books 8-11. W. Heinemann, London; Harvard University Press, Cambridge MA, 613 p. (Coll. Loeb Classical Library; 353).

Ramcharitar J., Gannon D. P. \& Popper A. N. 2006. - Bioacoustics of fishes of the family Sciaenidae (croakers and drums). Transactions of the American Fisheries Society 135 (5): 1409-1431. http://doi.org/10.1577/T05-207.1

RichARDSON N. J. \& KiRK G. S (ed.) 1993. - The Iliad: a commentary. Books 21-24. Volume VI. Cambridge University Press, Cambridge, $387 \mathrm{p}$.

RONDELET G. 1554. - Libri de piscibus marinis, in quibus verae piscium effigies expressae sunt. apud Matthiam Bonhomme, Lugduni.

SAINT-DENIS E. DE 1947. - Le Vocabulaire des animaux marins en latin classique. Klinksieck, Paris, 120 p.

SCHLEgel C. M. 2005. - Satire and the Threat of Speech. The University of Wisconsin Press, Madison, London, $186 \mathrm{p}$.

SCHOlfield A. F. (trans.) 2014. — Aelian. On Animals, Volume III: Books 12-17. Harvard University Press, Cambridge MA, 393 p. (Coll. Loeb Classical Library; 449).

STRABO: see JONES 1929.

STRÖMBERG R. 1943. - Studien zur Etymologie und Bildung der griechischen Fischnamen. Elanders Boktryckeri Aktiebolag, Göteborg, $165 \mathrm{p}$.

THOMAS R. F. 2008. - Tradition and meaning in Virgil's Georgics, in VOLK K. (ed.), Vergil's Georgics. Oxford University Press, Oxford: 43-80.

Thompson D. A. W. 1947. - A Glossary of Greek Fishes. Oxford University Press, Oxford, 302 p.

TiMOCLES AP. ATH.: see OlSON 2008.

Toohey P. 2004. - Melancholy, Love and Time: Boundaries of the Self in Ancient Literature. The University of Michigan Press, Ann Arbor, 386 p.

VARRO: see ASTBURY 2002

VOLPE M. 2004. — La pesca della corvina. http://www.apneamagazine. com/la-pesca-della-corvina-829 last consultation: 28/09/2016.

Warmington E. H. (trans.) 1938. - Remains of Old Latin, Volume III: Lucilius. The Twelve Tables. W. Heinemann, London; Harvard University Press, Cambridge MA, 549 p. (Coll. Loeb Classical Library; 329).

WysOcki L. E., CODARIN A., LADICH F. \& PiCCIULIN M. 2009. Sound pressure and particle acceleration audiograms in three marine fish species from the Adriatic Sea. The Journal of the Acoustical Society of America 126 (4): 2100-2107. 